\title{
ANALISIS PENGARUH P-DELTA EFFECT TERHADAP PERBEDAAN KETINGGIAN STRUKTUR GEDUNG TAHAN GEMPA (STUDI KASUS: NON-HIGHRISE BUILDING)
}

\author{
Heri Istiono ${ }^{1 *}$, Azhar Yusuf Ramadhan ${ }^{2}$ \\ ${ }^{1}$ Dosen / Jurusan Teknik Sipil, Fakultas Teknik Sipil dan Perencanaan / \\ Institut Teknologi Adhi Tama Surabaya \\ ${ }^{2}$ Mahasiswa / Jurusan Teknik Sipil, Fakultas Teknik Sipil dan Perencanaan / \\ Institut Teknologi Adhi Tama Surabaya \\ *Korespondensi: heri_istiono@itats.ac.id
}

\begin{abstract}
The need for earthquake resistant buildings in Indonesia is something that needs to be considered. Considering that Indonesia is an earthquake prone area. A building structure must be designed to be able to withstand lateral loads such as earthquakes within the limits set by the code/standards. For conservative reasons analysis of the P-Delta Effect needs to be considered because the building development ratio will always increase every time. according to SNI 1726-2019 the P-Delta effect is only required for the design of tall buildings. In this case, the P-Delta effect will be calculated in the modeling of non-high-rise buildings and get the results that P-Delta Effect increased story forces: moment of the building under $10 \%$.
\end{abstract}

Keyword: Earthquake, Non-Linear Analysis, P-Delta Effect, Pushover Analysis.

\section{PENDAHULUAN}

Korban yang diakibatkan oleh gempa bumi didominasi dari kejadian tertimpa reruntuhan bangunan yang runtuh karena suatu struktur gedung tidak mampu menahan beban gempa yang terjadi. Kebutuhan akan bangunan tahan gempa di Indonesia menjadi suatu hal yang perlu dipertimbangkan mengingat Indonesia merupakan daerah rawan gempa. Suatu struktur tinggi harus dirancang untuk dapat menahan beban lateral seperti gempa bumi dalam batas yang telah di tetapkan oleh standarisasi. Ketika suatu elemen struktur secara keseluruhan mengalami lateral displacement, struktur bangunan akan berubah bentuk atau berdeformasi yang menghasilkan momen guling. Eksentrisitas yang timbul tersebut menghasilkan momen internal tambahan yang dapat mempengaruhi momen hasil analisis.

Analisis tentang P-Delta Effect perlu dipertimbangkan dikarenakan kebutuhan bangunan tinggi dari waktu ke waktu akan selalu meningkat. Analisis dilakukan dengan metode P-Delta Statik sesuai SNI 2847-2012 dan P-Delta Dinamik menggunakan analisis pushover sesuai FEMA 356. Karena kerumitan perancangan $P$-Delta Effect, seringkali perencanaan hanya dilakukan sampai dengan tahapan analisa statis linear saja, hal ini nantinya dapat menjadi suatu penyebab kegagalan struktur pada bangunan bertingkat.[1]

\subsection{P-Delta Effect}

Beban gravitasi (P) yang memiliki pengaruh terhadap perpindahan horizontal $(\Delta)$ dikenal dengan sebutan $P$-Delta Effect. Ketika beban lateral akibat gempa bekerja pada suatu elemen struktural sehingga menyebabkan simpangan atau drift $(\Delta)$ yang mengakibatkan timbulnya eksentrisitas beban gravitasi (P) terhadap sumbu vertikal kolom, dari eksentrisitas yang timbul tersebut menghasilkan momen internal tambahan yang dapat mempengaruhi momen hasil analisis orde pertama.

$P$-Delta Effect yang terjadi berasal dari 2 sumber, yaitu perpindahan secara global pada batang kolom yang di akibatkan oleh beban 
lateral atau biasa di sebut dengan $P$-Large Delta $(\mathrm{P}-\Delta)$ dan deformasi lokal yang terjadi dari dalam batang kolom itu sendiri atau biasa disebut dengan $P$-Small Delta $(\mathrm{P}-\delta)$.

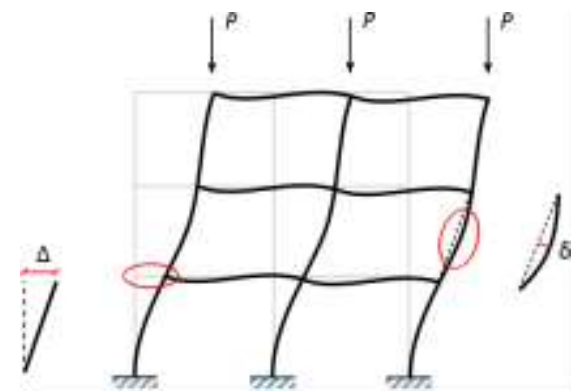

Gambar 1. Ilustrasi P-Large Delta $(\mathrm{P}-\Delta)$ dan P-Small Delta $(\mathrm{P}-\delta)$

\subsection{P-Delta Effect Statik}

Berdasarkan FEMA 356 C3.2.5 P-Delta Effect Statik terjadi akibat beban gravitasi yang bekerja melalui konfigurasi perubahan deformasi dari sebuah bangunan dan menghasilkan peningkatan pada lateral displacement.[2]

Pada SNI 1726-2019 pasal 7.8.7 pengaruh dari P-Delta tidak diperlukan untuk dilakukan perhitungan jika koefisien stabilitas $(\Theta)$ kurang dari atau sama dengan 0,10.[3]

\subsection{P-Delta Effect Dinamik}

Perhitungan P-Delta Effect dilakukan untuk mempertimbangkan penambahaan simpangan. Sejauh mana P-Delta Effect dinamik meningkatkan displacement sesuai dengan parameter berikut ini.

1. Perbandingan $\alpha$ dari kekakuan negatif pasca kelelehan dengan kekakuan efektif elastik.

2. Perioda dasar dari sebuah bangunan.

3. Strength ratio $(\mathrm{R})$

4. Deformasi beban hirsterestis untuk tiap tiap lantai.

5. Karakteristik frekuensi dari pergerakan tanah.

6. Durasi dari kekuatan pergerakan tanah.

Berdasarkan parameter tersebut, banyak parameter yang terlibat sehingga sulit jika mempertimbangkan $P$-Delta Effect dinamik menggunakan faktor modifikasi tunggal. Dengan demikian koefisien $\mathrm{C}_{3}$ mewakili penyederhanaan dari banyaknya parameter yang dipertimbangkan. Koefisien $\mathrm{C}_{3}$ dan $P$ Delta Effect dinamik akan diperhitungkan dalam analisis non-linear (Non-linear Dinamic Procedure) / analisis pushover.[2]

Pada penelitian ini akan dilakukan perbandingan prosentase besaran momen yang terjadi akibat penambahan $P$-Delta Effect dan tanpa penambahan P-Delta Effect terhadap ketinggian struktur gedung dengan beberapa variasi tingkatan masing masing gedung di bawah 40 meter.

\section{TINJAUAN PUSTAKA}

\subsection{Analisis respon spektrum}

\subsubsection{Geser Dasar Seismik}

Sesuai SNI 1726-2019 gaya geser dasar seismik diperoleh menggunakan rumus, berikut ini.

$$
\mathrm{V}=\mathrm{Cs} \mathrm{W}
$$

Dimana:

Cs $=$ Koefisien respon seismik

$\mathrm{W}=$ Berat seismik efektif

\subsubsection{Perioda Alami Fundamental}

Sesuai SNI 1726-2019 Periode Alami Fundamental diperoleh menggunakan perumusan berikut ini.

Ta minimum $=\mathrm{Ct} \mathrm{hn}{ }^{\mathrm{x}}$

$\mathrm{Ta}$ maximum $=\mathrm{Cu}$ Ta minimum

Dimana:

$\mathrm{Cu} \quad=$ Koefisien batas atas sesuai $\mathrm{S}_{\mathrm{D} 1}$

Ta $\min =$ Nimai batas bawah perioda

\subsubsection{Percepatan Gempa MCE $_{R}$}

Sesuai SNI 1726-2019 Percepatan Gempa Maksimum diperoleh menggunakan perumusan berikut ini.

$$
\begin{aligned}
& S_{\mathrm{MS}}=\mathrm{FaSs} \\
& \mathrm{S}_{\mathrm{M} 1}=\mathrm{Fv} \mathrm{S}_{1}
\end{aligned}
$$

Dimana:

$\mathrm{Fa}=$ Koefisien respon seismik

Ss $=$ Berat seismik efektif

Ss $=$ Berat seismik efektif

\subsubsection{Parameter Desain Spektrum}

Sesuai SNI 1726-2019 Parameter Desain Spektrum untuk periode diperoleh menggunakan perumusan berikut ini.

$$
\begin{aligned}
& \mathrm{S}_{\mathrm{MS}}=\mathrm{Fa} \mathrm{Ss} \\
& \mathrm{S}_{\mathrm{M} 1}=\mathrm{Fv} \mathrm{S}_{1}
\end{aligned}
$$

Dimana:

$\mathrm{Fa}=$ Koefisien respon seismik

Ss $=$ Berat seismik efektif

Ss $=$ Berat seismik efektif 


\subsubsection{Kombinasi Pembebanan}

Sesuai SNI 1726-2019 Parameter Desain Spektrum untuk periodekombinasi dan pengaruh beban gempa diperoleh menggunakan kombinasi berikut.

$1,4 \mathrm{DL}$

$1,2 \mathrm{DL}+1,6 \mathrm{LL}+0,5 \mathrm{Lr}$

$1,2 \mathrm{DL}+1 \mathrm{LL}+1,6 \mathrm{Lr}$

$1,2 \mathrm{DL}+1 \mathrm{LL}+\mathrm{Ey}+\mathrm{Eh}$

$0,9 \mathrm{DL}-\mathrm{Ev}+\mathrm{Eh}$

$1,0 \mathrm{DL}+0,7 \mathrm{Ev}+0,7 \mathrm{Eh}$

$1,0 \mathrm{DL}-0,75 \mathrm{LL}+0,525 \mathrm{Ev}+0,525 \mathrm{Eh}(14)$

$1,0 \mathrm{DL}+0,7 \mathrm{Ev}+0,7 \mathrm{Eh}$

Dimana:

DL $=$ Beban mati

$\mathrm{LL}=$ Beban hidup

$\mathrm{Lr}=$ Pengaruh beban hidup di atap

$\mathrm{Ex}=$ Beban gempa arah-x

Ey $=$ Berat seismik efektif

Ey $=$ Berat seismik efektif

\subsubsection{Simpangan Antar Lantai}

Sesuai SNI 1726-2019 Simpangan antar lantai diperoleh menggunakan perumusan berikut ini.

$$
\delta_{\mathrm{x}}=\frac{c_{d} \delta_{x e}}{I_{e}}
$$

Dimana:

$\mathrm{C}_{\mathrm{d}}=$ Faktor amplifikasi defleksi

$\delta_{\mathrm{xe}}=$ Defleksi pada lokasi

$\mathrm{I}_{\mathrm{e}}=$ Faktor keutamaan gempa

\subsubsection{P-delta effect}

Sesuai SNI 1726-2019 koefisien stabilitas diperoleh menggunakan perumusan berikut ini.

$$
\begin{gathered}
\Theta=\frac{P_{x} \Delta I_{e}}{V_{x} h_{s x} C_{d}} \\
\Theta_{\max }=\frac{0,5}{\beta C_{d}}<25
\end{gathered}
$$

Dimana:

$\mathrm{Px}=$ Beban desain vertikal $\mathrm{x}$ dan diatas $\mathrm{x}$

$\Delta=$ Simpangan antar lantai

Ie $=$ Faktor keutamaan gempa

$\mathrm{Vx}=$ Gaya geser akibat seismik

$\mathrm{h}_{\mathrm{sx}}=$ Ketinggian di bawah tingkat $\mathrm{x}$

$\mathrm{Cd}=$ Faktor pembesaran defleksi

$\beta=$ Ratio kebutuhan geser terhadap

kapasitas geser tingkat yang ditinjau

Untuk mendefinisikan P-Delta Effect pada ETABS dilakukan dengan memilih tab define $\rightarrow$ P-Delta Options, dengan demikian maka akan muncul taskbar sebagai berikut.

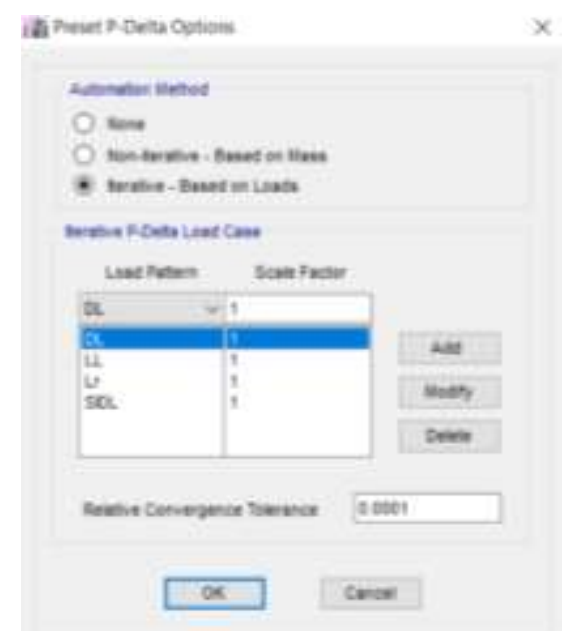

Gambar 2. Pendefinisian P-Delta ETABS

Pada taskbar preset P-Delta options centang pada bagian iterative - Based on Loads, dengan masing masing beban menggunakan scale factor sebesar 1,00 hal ini sesuai dengan FEMA 356 untuk memperhitungkan pengaruh P-Delta menggunakan unfactor load.[2]

\subsection{Analisis Pushover}

Analisis pushover adalah analisa statik non-linear yang dilakukan untuk mengetahui perilaku keruntuhan suatu struktur bangunan dengan cara memberikan pola beban lateral static kemudian beban akan terus ditambah dengan faktor pengali secara berangsur-angsur.

Analisa pushover dilakukan menggunakan model 2 dimensi dikarenakan sulit menemukan beban runtuh dan mekanisme keruntuhan jika menggunakan model 3 dimensi. Dengan demikian pada penilitian ini analisis pushover dilakukan menggunakan model 2 dimensi. [4]

Target displacement $\left(\delta_{\mathrm{T}}\right)$ adalah perpindahan global maksimum (elastis dan inelastis) [2] yang didapat dari perhitungan dengan faktor koefisien $\mathrm{C}_{0}, \mathrm{C}_{1}, \mathrm{C}_{2}$ dan $\mathrm{C}_{3}$. Target displacement $\left(\delta_{\mathrm{T}}\right)$ pada pasal 3.3.3.3.2 FEMA 356 diperoleh dengan persamaan berikut ini.

$$
\delta_{\mathrm{T}}=\mathrm{C}_{0} \mathrm{C}_{1} \mathrm{C}_{2} \mathrm{C}_{3} \frac{T e^{\wedge} 2}{4 \pi^{\wedge} 2} \mathrm{~g}
$$

Dinama:

$\mathrm{T}_{\mathrm{e}}=$ Waktu getar efektif

$\delta_{\mathrm{T}}=$ Target displacement

$\mathrm{C}_{0}=$ Faktor modifikasi untuk perpindahan spektral menjadi perpindahan atap 
$\mathrm{C}_{1}=$ Faktor modifikasi untuk menghubungkan perpindahan inelastic maksimum dengan perpindahan yang dihitung dari respon elastik linier.

$\mathrm{C}_{2}=$ Faktor modifikasi yang mewakili efek dari bentuk hirterestis pada perpindahan maksimum,

$\mathrm{C}_{3}=$ Koefisien untuk mempertimbangkan pembesaran lateral akibat $P$-Delta Effect

$\mathrm{g}=$ Percepatan gravitasi $9,81 \mathrm{~m} /$ detik $^{2}$

Setelah peformace point ditemukan, ratio antara displacement maksimum yang terjadi harus dibandingkan dengan ketinggian gedung sehingga didapatkan level kinerja struktur sesuai dengan Tabel 1.

Tabel 1. Level Kinerja

\begin{tabular}{cc}
\hline Level Kinerja & Drift Ratio \\
\hline IO (Immediate Occupancy) & $1 \%$ \\
\hline LS (Life Safety) & $2 \%$ \\
\hline CP (Collapse Prevention) & $4 \%$ \\
\hline
\end{tabular}

\section{METODOLOGI PENELITIAN}

\subsection{Data Pemodelan}

Pemodelan menggunakan 3 gedung fiksional, dengan pertimbangan masing masing gedung memiliki ketinggian kurang dari 40 meter atau masuk dalam kategori non-high rise building sesuai ketentuan SNI 1726-2002.

Tabel 2. Data Pemodelan Gedung.

\begin{tabular}{lccc}
\hline & Ged A & Ged B & Ged C \\
\hline Denah & \multicolumn{2}{c}{45 meter x 42} & meter \\
\hline Jumlah & 6 & 8 & 10 \\
Lantai & Lantai & Lantai & Lantai \\
\hline $\begin{array}{l}\text { Tinggi Antar } \\
\text { Lantai }\end{array}$ & 4 meter & \\
\hline Jarak X dir & 6 meter \\
\hline Jarak Y dir & 5 meter \\
\hline Sistem & Sistem Rangka Pemikul \\
Struktur & Momen Khusus \\
\hline Perletakan & \multicolumn{2}{c}{ Penjepitan lateral } \\
\hline Klasifikasi & SD (Tanah Sedang) \\
\hline Kat. Risiko & \multicolumn{2}{c}{ II } \\
\hline Fakor & 1,0 \\
Keutamaan & \multicolumn{2}{c}{} \\
\hline
\end{tabular}

\subsection{Model dan konfigurasi gedung}

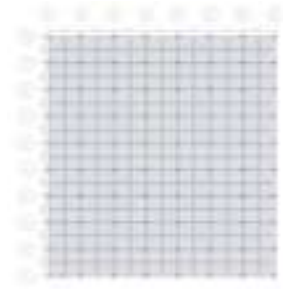

Gambar 3. Denah Lantai

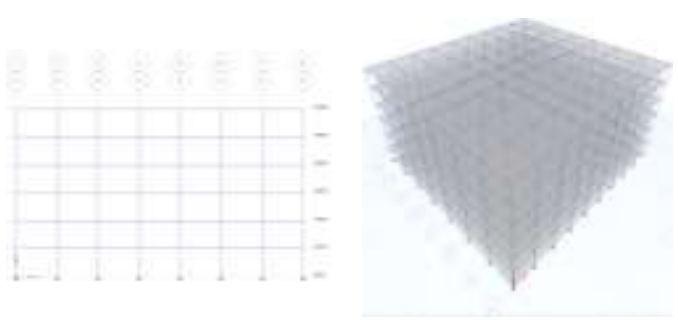

Gambar 4. Gedung A (6 Lantai / 24 meter)

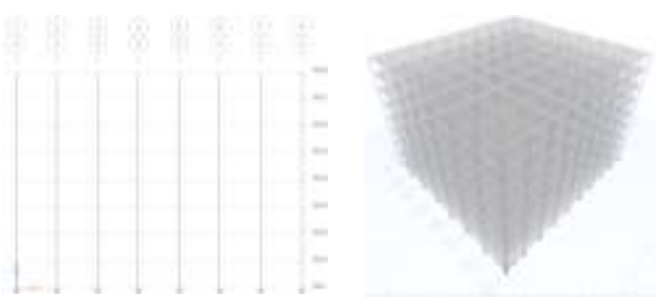

Gambar 5. Gedung B (8 Lantai / 32 meter

\subsection{Material Properties}

Material properties yang digunakan memiliki perbedaan pada mutu kolom dengan pertimbangan kaidah perencanaan sesuai dengan SCWB (Strong Column Weak Beam) pada masing masing pemodelan gedung sebagai berikut:

Tabel 3. Material Properties

\begin{tabular}{lc}
\hline & Keterangan \\
\hline Mutu Beton Balok & $35 \mathrm{Mpa}$ \\
\hline Mutu Beton Pelat & $35 \mathrm{Mpa}$ \\
\hline Mutu Beton Kolom & $45 \mathrm{Mpa}$ \\
\hline
\end{tabular}




\subsection{Section Properties}

Dimensi elemen struktural pada masing masing pemodelan gedung adalah sebagai berikut:

Tabel 4. Section Properties

\begin{tabular}{lc} 
Elemen Struktur & Dimensi \\
\hline Balok (B1) & $450 \mathrm{~mm} \times 250 \mathrm{~mm}$ \\
\hline Balok (B2) & $500 \mathrm{~mm} \times 250 \mathrm{~mm}$ \\
\hline Kolom & $500 \mathrm{~mm} \times 500 \mathrm{~mm}$ \\
\hline Tebal Pelat Lantai & $150 \mathrm{~mm}$ \\
\hline
\end{tabular}

\subsection{Pembebanan}

Beban yang bekerja pada masing masing pemodelan gedung adalah sama dan didefinisikan sebagai berikut:

Tabel 5. Detail Pembebanan. Beban Gravitasi

\begin{tabular}{|c|c|}
\hline Dead Load (DL) & $\begin{array}{c}\text { Didapatkan dari } \\
\text { ETABS }\end{array}$ \\
\hline Live Load (LL) & $1,92 \mathrm{kN} / \mathrm{m}^{2}$ \\
\hline Live Roof (Lr) & $0,96 \mathrm{kN} / \mathrm{m}^{2}$ \\
\hline \multicolumn{2}{|c|}{ SIDL (Super Impossed Dead Load) } \\
\hline Keramik Spesi & $1,10 \mathrm{kN} / \mathrm{m}^{2}$ \\
\hline Ducting Mekanikal & $0,19 \mathrm{kN} / \mathrm{m}^{2}$ \\
\hline Penggantung Plafon & $0,1 \mathrm{kN} / \mathrm{m}^{2}$ \\
\hline Plafon & $0,05 \mathrm{kN} / \mathrm{m}^{2}$ \\
\hline Waterproofing & $0,39 \mathrm{kN} / \mathrm{m}^{2}$ \\
\hline
\end{tabular}

Untuk beban gempa yang bekerja dilakukan perhitungan pada parameter respon spektrum dengan lokasi Surabaya.

\section{HASIL DAN PEMBAHASAN}

\subsection{Parameter Response Spectrum}

Response spectrum yang digunakan dihitung berdasarkan SNI 1726-2019 dengan redaman kritis $5 \%$.

Tabel 6. Parameter Respon Spektrum Parameter Respons Spektra

\begin{tabular}{cc}
\hline Kategori Risiko & II \\
\hline Ie & 1 \\
\hline Klasifikasi Situs & SD \\
\hline Ss & 0,75 \\
\hline $\mathbf{S}_{\mathbf{1}}$ & 0,35 \\
\hline $\mathbf{F}_{\mathbf{A}}$ & 1,20 \\
\hline $\mathbf{F v}_{\mathbf{V}}$ & 2,00 \\
\hline $\mathbf{S}_{\mathbf{M S}}$ & 0,90 \\
\hline $\mathbf{S}_{\mathbf{M} 1}$ & 0,60 \\
\hline $\mathbf{S}_{\text {DS }}$ & 0,60 \\
\hline
\end{tabular}

\begin{tabular}{cc}
\hline $\mathbf{S}_{\mathbf{D} 1}$ & 0,47 \\
\hline $\mathbf{T}_{\mathbf{0}}$ & 0,133 \\
\hline $\mathbf{T}_{\mathbf{S}}$ & 0,667 \\
\hline \multicolumn{2}{c}{ Parameter Sistem Rangka Pemikul } \\
Momen Khusus Beton Bertulang \\
\hline $\mathbf{R}$ & 8 \\
\hline $\mathbf{\Omega}$ & 3 \\
\hline $\mathbf{C d}$ & 5,5 \\
\hline
\end{tabular}

Setelah didapatkan masing masing parameter response spectrum, selanjutnya dihitung dan ditabelkan pada Tabel 7.

Untuk $\mathrm{T}<\mathrm{T}_{0}$ maka, $\mathrm{S}_{\mathrm{a}}=\mathrm{S}_{\mathrm{DS}}\left(0,4+0,6 \mathrm{~T} / \mathrm{T}_{0}\right)$

Untuk $\mathrm{T}_{0} \leq \mathrm{T} \leq \mathrm{T}_{\mathrm{s}}$ maka, $\mathrm{S}_{\mathrm{a}}=\mathrm{S}_{\mathrm{DS}}$

Untuk $\mathrm{T} \geq \mathrm{T}_{\mathrm{s}}$ maka, $\mathrm{S}_{\mathrm{a}}=\mathrm{S}_{\mathrm{D} 1} / \mathrm{T}$

Tabel 7. Respon Percepatan Desain

\begin{tabular}{cccccc}
\hline $\mathbf{T}(\mathbf{d t})$ & $\mathbf{S}_{\mathrm{A}}(\mathbf{g})$ & Ket. & $\mathbf{T}(\mathbf{d t})$ & $\mathbf{S}_{\mathrm{A}}(\mathbf{g})$ & Ket. \\
\hline $\mathbf{0 . 0 0}$ & 0.240 & $\mathrm{~T} \leq \mathrm{T}_{0}$ & 2.10 & 0.190 & $\mathrm{~T} \geq \mathrm{T}_{\mathrm{S}}$ \\
\hline $\mathbf{0 . 1 0}$ & 0.510 & $\mathrm{~T} \leq \mathrm{T}_{0}$ & 2.20 & 0.182 & $\mathrm{~T} \geq \mathrm{T}_{\mathrm{S}}$ \\
\hline $\mathbf{0 . 2 0}$ & 0.600 & $\mathrm{~T}_{0} \leq \mathrm{T} \leq \mathrm{T}_{\mathrm{S}}$ & 2.30 & 0.174 & $\mathrm{~T} \geq \mathrm{T}_{\mathrm{S}}$ \\
\hline $\mathbf{0 . 3 0}$ & 0.600 & $\mathrm{~T}_{0} \leq \mathrm{T} \leq \mathrm{T}_{\mathrm{S}}$ & 2.40 & 0.167 & $\mathrm{~T} \geq \mathrm{T}_{\mathrm{S}}$ \\
\hline $\mathbf{0 . 4 0}$ & 0.600 & $\mathrm{~T}_{0} \leq \mathrm{T} \leq \mathrm{T}_{\mathrm{S}}$ & 2.50 & 0.160 & $\mathrm{~T} \geq \mathrm{T}_{\mathrm{S}}$ \\
\hline $\mathbf{0 . 5 0}$ & 0.600 & $\mathrm{~T}_{0} \leq \mathrm{T} \leq \mathrm{T}_{\mathrm{S}}$ & 2.60 & 0.154 & $\mathrm{~T} \geq \mathrm{T}_{\mathrm{S}}$ \\
\hline $\mathbf{0 . 6 0}$ & 0.600 & $\mathrm{~T}_{0} \leq \mathrm{T} \leq \mathrm{T}_{\mathrm{S}}$ & 2.70 & 0.148 & $\mathrm{~T} \geq \mathrm{T}_{\mathrm{S}}$ \\
\hline $\mathbf{0 . 7 0}$ & 0.571 & $\mathrm{~T} \geq \mathrm{T}_{\mathrm{S}}$ & 2.80 & 0.143 & $\mathrm{~T} \geq \mathrm{T}_{\mathrm{S}}$ \\
\hline $\mathbf{0 . 8 0}$ & 0.500 & $\mathrm{~T} \geq \mathrm{T}_{\mathrm{S}}$ & 2.90 & 0.138 & $\mathrm{~T} \geq \mathrm{T}_{\mathrm{S}}$ \\
\hline $\mathbf{0 . 9 0}$ & 0.444 & $\mathrm{~T} \geq \mathrm{T}_{\mathrm{S}}$ & 3.10 & 0.133 & $\mathrm{~T} \geq \mathrm{T}_{\mathrm{S}}$ \\
\hline $\mathbf{1 . 0 0}$ & 0.400 & $\mathrm{~T} \geq \mathrm{T}_{\mathrm{S}}$ & 3.20 & 0.129 & $\mathrm{~T} \geq \mathrm{T}_{\mathrm{S}}$ \\
\hline $\mathbf{1 . 1 0}$ & 0.364 & $\mathrm{~T} \geq \mathrm{T}_{\mathrm{S}}$ & 2.10 & 0.190 & $\mathrm{~T} \geq \mathrm{T}_{\mathrm{S}}$ \\
\hline $\mathbf{1 . 2 0}$ & 0.333 & $\mathrm{~T} \geq \mathrm{T}_{\mathrm{S}}$ & 2.20 & 0.182 & $\mathrm{~T} \geq \mathrm{T}_{\mathrm{S}}$ \\
\hline $\mathbf{1 . 3 0}$ & 0.308 & $\mathrm{~T} \geq \mathrm{T}_{\mathrm{S}}$ & 2.30 & 0.174 & $\mathrm{~T} \geq \mathrm{T}_{\mathrm{S}}$ \\
\hline $\mathbf{1 . 4 0}$ & 0.286 & $\mathrm{~T} \geq \mathrm{T}_{\mathrm{S}}$ & 2.40 & 0.167 & $\mathrm{~T} \geq \mathrm{T}_{\mathrm{S}}$ \\
\hline $\mathbf{1 . 5 0}$ & 0.267 & $\mathrm{~T} \geq \mathrm{T}_{\mathrm{S}}$ & 3.30 & 0.121 & $\mathrm{~T} \geq \mathrm{T}_{\mathrm{S}}$ \\
\hline $\mathbf{1 . 4 0}$ & 0.286 & $\mathrm{~T} \geq \mathrm{T}_{\mathrm{S}}$ & 3.40 & 0.118 & $\mathrm{~T} \geq \mathrm{T}_{\mathrm{S}}$ \\
\hline $\mathbf{1 . 6 0}$ & 0.250 & $\mathrm{~T} \geq \mathrm{T}_{\mathrm{S}}$ & 3.50 & 0.114 & $\mathrm{~T} \geq \mathrm{T}_{\mathrm{S}}$ \\
\hline $\mathbf{1 . 7 0}$ & 0.235 & $\mathrm{~T} \geq \mathrm{T}_{\mathrm{S}}$ & 3.60 & 0.111 & $\mathrm{~T} \geq \mathrm{T}_{\mathrm{S}}$ \\
\hline $\mathbf{1 . 8 0}$ & 0.222 & $\mathrm{~T} \geq \mathrm{T}_{\mathrm{S}}$ & 3.70 & 0.108 & $\mathrm{~T} \geq \mathrm{T}_{\mathrm{S}}$ \\
\hline $\mathbf{1 . 9 0}$ & 0.211 & $\mathrm{~T} \geq \mathrm{T}_{\mathrm{S}}$ & 3.80 & 0.105 & $\mathrm{~T} \geq \mathrm{T}_{\mathrm{S}}$ \\
\hline $\mathbf{2 . 0 0}$ & 0.200 & $\mathrm{~T} \geq \mathrm{T}_{\mathrm{S}}$ & 3.90 & 0.103 & $\mathrm{~T} \geq \mathrm{T}_{\mathrm{S}}$ \\
\hline
\end{tabular}

Dari hasil tabel tersebut dibuat grafik Spectra Acceleration (Sa) vs Periode (T). pada Gambar 6.

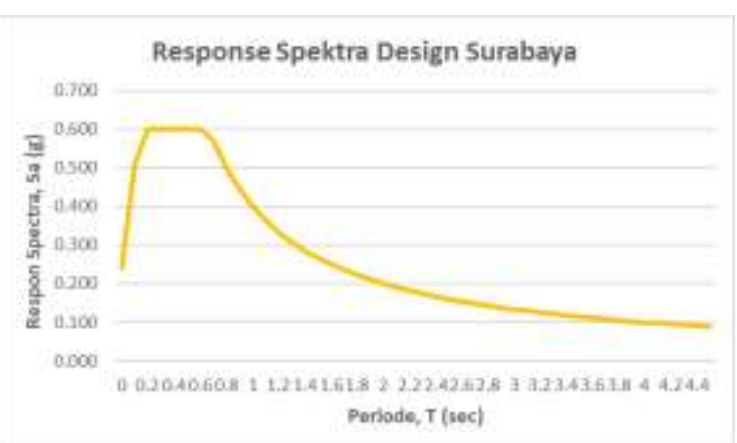

Gambar 6. Grafik Respon Spektrum Untuk Wilayah Surabaya 


\subsection{Kombinasi pembebanan}

Kombinasi pembebanan dihitung dan ditabelkan pada Tabel 8 sesuai dengan $\rho$ dan $\mathrm{S}_{\mathrm{DS}}$ untuk wilayah Surabaya.

Tabel 8. Tabel Kombinasi Pembebanan Untuk $\rho=1,3$ dan $S_{D S}=0,60$

\begin{tabular}{ccccccc}
\hline Comb & DL & SIDL & LL & Lr & Ex & Ey \\
\hline $\mathbf{1}$ & 1,40 & 1.40 & & & & \\
\hline $\mathbf{2}$ & 1,20 & 1,20 & 1,60 & 0,50 & & \\
$\mathbf{3}$ & 1,20 & 1,20 & 1,00 & 1,60 & & \\
\hline
\end{tabular}

\begin{tabular}{cccccl}
\hline \multicolumn{6}{c}{ Kombinasi pembebanan dengan pengaruh gempa } \\
\hline $\mathbf{4}$ & 1,35 & 1,35 & 1,00 & 0,39 & 1,30 \\
\hline $\mathbf{5}$ & 1,11 & 1,11 & 1,00 & 0,39 & $-1,30$ \\
\hline $\mathbf{6}$ & 1,04 & 1,04 & 1,00 & $-0,39$ & 1,30 \\
\hline $\mathbf{7}$ & 1,28 & 1,28 & 1,00 & $-0,39$ & $-1,30$ \\
\hline $\mathbf{8}$ & 1,35 & 1,35 & 1,00 & 1,30 & 0,39 \\
\hline $\mathbf{9}$ & 1,28 & 1,28 & 1,00 & 1,30 & $-0,39$ \\
\hline $\mathbf{1 0}$ & 1,04 & 1,04 & 1,00 & $-1,30$ & 0,39 \\
\hline $\mathbf{1 1}$ & 1,11 & 1,11 & 1,00 & $-1,30$ & $-0,39$ \\
\hline $\mathbf{1 2}$ & 0,74 & 0,74 & 0,39 & 1,30 \\
\hline $\mathbf{1 3}$ & 0,98 & 0,98 & 0,39 & $-1,30$ \\
\hline $\mathbf{1 4}$ & 1,05 & 1,05 & $-0,39$ & 1,30 \\
\hline $\mathbf{1 5}$ & 0,81 & 0,81 & $-0,39$ & $-1,30$ \\
\hline $\mathbf{1 6}$ & 0,74 & 0,74 & \multicolumn{4}{c}{1,30} & 0,39 \\
\hline $\mathbf{1 7}$ & 0,81 & 0,81 & 1,30 & $-0,39$ \\
\hline $\mathbf{1 8}$ & 1,05 & 1,05 & \multicolumn{5}{c}{$-1,30$} & 0,39 \\
\hline $\mathbf{1 9}$ & 0,98 & 0,98 & \multicolumn{5}{c}{$-1,30$} \\
\hline Ex Max & \multicolumn{5}{c}{ Diambil dari hasil gempa arah X terbesar } \\
\hline Ey Max & \multicolumn{5}{c}{ Diambil dari hasil gempa arah Y terbesar } \\
\hline Service & 1,00 & 1,00 & 1,00 & 1,00 \\
\hline \multicolumn{5}{c}{} \\
\hline
\end{tabular}

\subsection{Periode Getar}

Pengaruh P-Delta Effect memberikan pengaruh pada masing masing periode getar untuk masing masing gedung sesuai tabel berikut.

Tabel 9. Periode Gedung A

$\begin{array}{lccc}\text { Periode } & \begin{array}{c}\text { Non P-D } \\ \text { (Detik) }\end{array} & \begin{array}{c}\text { P-D } \\ \text { (Detik) }\end{array} & \%\end{array}$

\begin{tabular}{cccc}
\hline Arah X & 1,172 & 1,180 & $0,67 \%$ \\
\hline Arah Y & 1,150 & 1,165 & $0,12 \%$ \\
\hline
\end{tabular}

Perbandingan periode getar yang terjadi pada gedung A dengan pengaruh P-Delta dan tanpa pengruh P-Delta masing masing arah memiliki perbedaan kurang dari $1 \%$ yaitu sebesar $0,67 \%$ untuk arah $\mathrm{X}$ dan $0,12 \%$ pada arah Y.
Tabel 10. Periode Gedung B

\begin{tabular}{lccc} 
Periode & $\begin{array}{c}\text { Non P- } \\
\text { D } \\
\text { (Detik) }\end{array}$ & $\begin{array}{c}\text { P-D } \\
\text { (Detik) }\end{array}$ & \% \\
\hline Arah X & 1,591 & 1,622 & $1,91 \%$ \\
\hline Arah Y & 1,560 & 1,589 & $1,81 \%$ \\
\hline
\end{tabular}

Perbandingan periode getar yang terjadi pada gedung $\mathrm{B}$ dengan pengaruh P-Delta dan tanpa pengruh P-Delta masing masing arah memiliki perbedaan lebih dari $1 \%$ yaitu sebesar $1,91 \%$ untuk arah $\mathrm{X}$ dan $1,81 \%$ pada arah Y.

Dari hasil tersebut didapatkan bahwa semakin tinggi gedung yang ditinjau maka selisih periode getar dengan pengaruh P-Delta dan tanpa Pengaruh P-Delta mengalami peningkatan.

\subsection{Story forces: moment}

Pengaruh P-Delta Effect mempengaruhi momen pada tiap lantai, berikut hasil perbandingan momen pada masing masing gedung dengan mempertimbangakan besaran pengaruh P-Delta dan Non P-Delta.

Tabel 11. Moment Gedung A

\begin{tabular}{cccc}
\hline Lantai & $\begin{array}{c}\text { Momen } \\
\text { Tanpa P- } \\
\text { delta } \\
\text { (kN-m) }\end{array}$ & $\begin{array}{c}\text { Momen } \\
\text { dengan } \\
\text { P-delta } \\
\text { (kN-m) }\end{array}$ & $\begin{array}{c}\text { Presentase } \\
\text { Perbesaran } \\
\text { Momen }\end{array}$ \\
\hline $\mathbf{1}$ & 55513,24 & 56031,94 & $9,3 \%$ \\
\hline $\mathbf{2}$ & 39137,66 & 39355,98 & $5,6 \%$ \\
\hline $\mathbf{3}$ & 24613,34 & 24645,16 & $2,8 \%$ \\
\hline $\mathbf{4}$ & 12698,27 & 12662,34 & $1,3 \%$ \\
\hline $\mathbf{5}$ & 4177,069 & 4150,443 & $0,64 \%$ \\
\hline $\mathbf{6}$ & 0 & 0 & $0 \%$ \\
\hline
\end{tabular}

Pada gedung A dapat dilihat sesuai dengan Tabel 11 bahwa besaran perbedaan momen pada tiap lantai dengan mempertimbangkan pengaruh P-Delta dan tidak mempertimbangkan pengaruh P-Delta terjadi perbedaan pada tiap lantai dengan selisih terbesar terjadi pada lantai 1 sebesar $9,3 \%$.

Hal tersebut juga terjadi pada gedung B dapat dilihat sesuai dengan Tabel 12 bahwa besaran perbedaan momen pada tiap lantai dengan mempertimbangkan pengaruh P-Delta dan tidak mempertimbangkan pengaruh $\mathrm{P}$ Delta terjadi perbedaan pada tiap lantai dengan selisih terbesar terjadi pada lantai 1 sebesar $3,62 \%$ 
Tabel 12. Moment Gedung B

\begin{tabular}{cccc}
\hline Lantai & $\begin{array}{c}\text { Momen } \\
\text { Tanpa } \\
\text { P-delta } \\
\text { (kN-m) }\end{array}$ & $\begin{array}{c}\text { Momen } \\
\text { dengan } \\
\text { P-delta } \\
\text { (kN-m) }\end{array}$ & $\begin{array}{c}\text { Presentase } \\
\text { Perbesaran } \\
\text { Momen }\end{array}$ \\
\hline $\mathbf{1}$ & 56966,59 & 59029,19 & $3,62 \%$ \\
\hline $\mathbf{2}$ & 44531,55 & 45951,62 & $3,19 \%$ \\
\hline $\mathbf{3}$ & 32894,81 & 33767,9 & $2,65 \%$ \\
\hline $\mathbf{4}$ & 22471,06 & 22940,21 & $2,09 \%$ \\
\hline $\mathbf{5}$ & 13638,38 & 13844,39 & $1,51 \%$ \\
\hline $\mathbf{6}$ & 6742,322 & 6805,403 & $0,94 \%$ \\
\hline $\mathbf{7}$ & 2099,464 & 2107,509 & $0,38 \%$ \\
\hline $\mathbf{8}$ & 0 & 0 & $0 \%$ \\
\hline
\end{tabular}

\subsection{Simpangan antar lantai (story drift)}

Simpangan antar lantai yang terjadi pada masing masing pemodelan gedung didapatkan dengan persamaan (16) diambil pada kombinasi pembebanan Ex max dan Ey max dari hasil output ETABS pada diaphragm center of mass displacement dan harus tidak lebih dari simpangan izin sebesar $2 \%$ dari total tinggi antar lantai $\left(\mathrm{h}_{\mathrm{sx}}\right)$ pada masing masing gedung, dengan tinggi antar lantai $4000 \mathrm{~mm}$ maka batasan izin simpangan antar lantai pada semua pemodelan gedung sebesar $0,02 \times 4000 \mathrm{~mm}=$ $80 \mathrm{~mm}$.

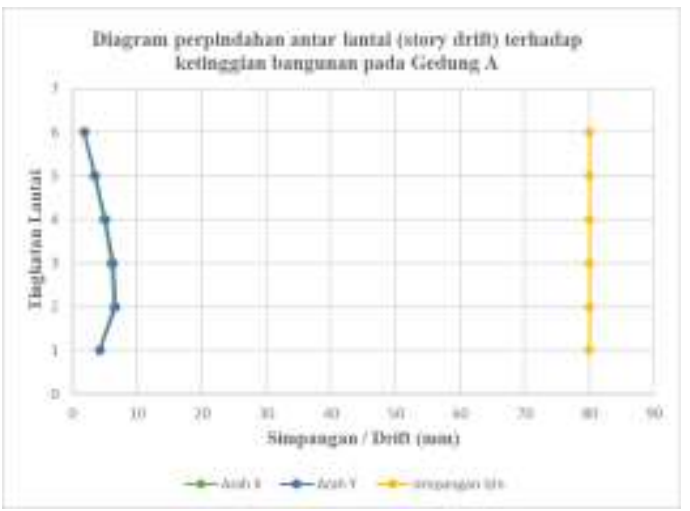

Gambar 7. Grafik Story Drift Gedung A

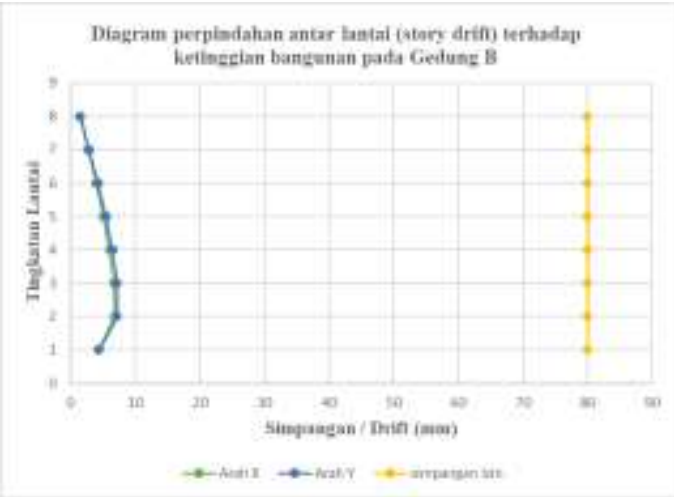

Gambar 8 Grafik Story Drift Gedung B
Dari grafik simpangan antar lantai pada masing masing pemodelan gedung pada Gambar 7 dan Gambar 8 menunjukan bahwa simpangan antar lantai yang terjadi pada masing masing gedung tidak ada yang melampaui dari batasan izin sesuai SNI 17262019.

\subsection{Displacement}

Pengaruh P-Delta juga mempengaruhi perbedaan Top story displacement pada masing masing pemodelan sesuai tabel berikut.

Tabel 13. Displacement atap.

\begin{tabular}{ccccc}
\hline \multirow{2}{*}{ Ged } & \multicolumn{2}{c}{$\begin{array}{c}\text { Non P- } \\
\text { Delta }\end{array}$} & \multicolumn{2}{c}{ P-Delta } \\
\cline { 2 - 5 } & \multicolumn{1}{c}{$\mathbf{X}$} & \multicolumn{1}{c}{$\mathbf{Y}$} & $\mathbf{X}$ & \multicolumn{1}{c}{$\mathbf{Y}$} \\
\hline A & 3,20 & 0,01 & 3,30 & 0,01 \\
& & 1 & & 2 \\
\hline B & 3,40 & 0,01 & 3,50 & 0,01 \\
& & 2 & & 3 \\
\hline
\end{tabular}

\subsection{P-delta statik}

Pada pengecekan P-Delta Statik teta yang terjadi pada tiap lantai harus dicari menggunakan menggunakan persamaan (17) dan tidak boleh melebihi teta max $\left(\theta_{\max }\right)$ sesuai persamaan (18).

Dengan $\beta$ pada teta max diambil secara konservatif besar 1 sesuai SNI 1726-2019 maka $\Theta_{\max }=0,5 /(1 \times 5,5)=0,09$ dan kurang dari 0,25 . Sehingga emax yang digunakan sebagai Batasan izin adalah sebesar 0,25.

Dari Gambar 9 dan Gambar 10, menunjukan bahwa pengecekan P-delta Statik pada masing masing gedung tidak ada yang melebihi $\Theta_{\max }$ sehingga tidak gedung berada pada kondisi stabil dan tidak perlu dilakukan desain ulang.

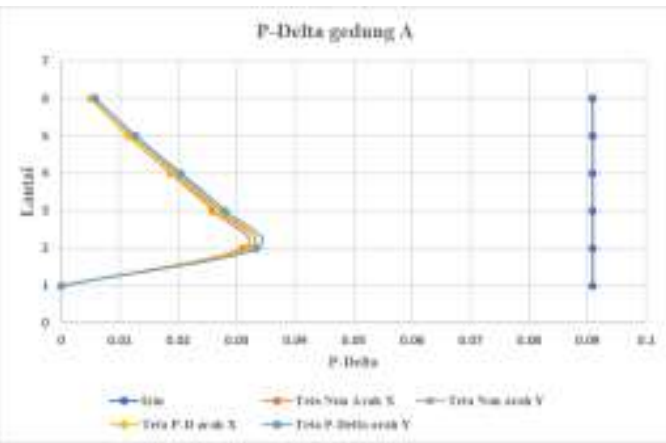

Gambar 9. P-Delta Statik Gedung A 


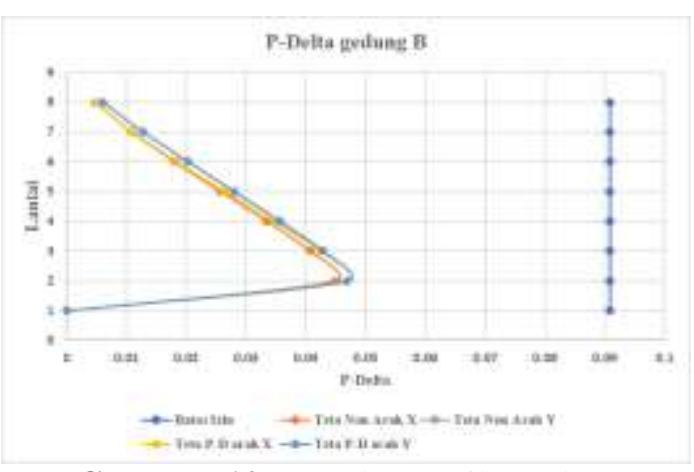

Gambar 10. P-Delta Statik Gedung B

Karena sesuai FEMA-356 jika terdapat teta $(\theta)$ yang melebihi teta max $\left(\theta_{\max }\right)$ maka kondisi gedung tersebut tidak stabil dan perlu dilakukan desain ulang. Berikut pengecekan pengaruh P-Delta pada masing masing gedung dilakukan plot pada grafik perbandingan PDelta pada tiap lantai.

\subsection{Analisis pushover dan P-Delta dinamik}

Pada analisis Pushover didapatkan performance point dari output ETABS dengan cara masuk pada tab display $\rightarrow$ static pushover curve untuk masing masing pemodelan gedung dengan kurva kapasitas Gambar 11, Gambar 12 dan ditabelkan pada Tabel 14.

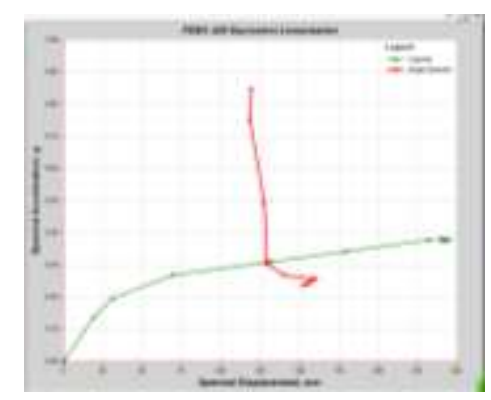

Gambar 11. Kurva kapasitas Gedung A

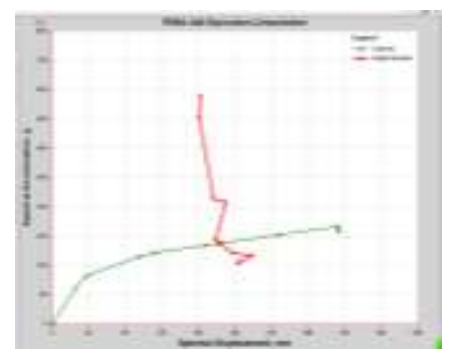

Gambar 12. Kurva kapasitas Gedung B

Hasil performance point yang didapatkan dari output ETABS ditabelkan pada Tabel 14.
Tabel 14. Hasil performance point

\begin{tabular}{cll}
\hline Gedung & Peformance & Keterangan \\
\hline Gedung B & Point Found & Yes \\
\cline { 2 - 3 } 32 $\mathbf{~}$ & Sa & 0,221 \\
\cline { 2 - 3 } & Sd & 184,202 \\
\cline { 2 - 3 } & T secant & 1,824 \\
\cline { 2 - 3 } & T effective & 1,803 \\
\hline Gedung A & Point Found & Yes \\
\cline { 2 - 3 } $\mathbf{2 4} \mathbf{~ m}$ & Sa & 0,309 \\
\cline { 2 - 3 } & Sd & 219,21 \\
\cline { 2 - 3 } & T secant & 1,295 \\
\cline { 2 - 3 } & T effective & 1,269 \\
\hline
\end{tabular}

Dari kurva base shear dibandingkan dengan displacement yang di dapat dari program bantu ETABS, maximum displacement pada masing masing gedung telah melampaui Target displacement.yang diperhitungkan dengan perumusan (19).

$$
\begin{aligned}
& \mathrm{C} 0=1,2 \text { (FEMA } 356 \text { Tabel 3-2) } \\
& \mathrm{C} 1=1,0 \\
& \mathrm{C} 2=1,0 \text { (FEMA } 356 \text { Tabel 3-3) } \\
& \mathrm{C} 3=1,0 \text { (Kurva kapasitas naik) }
\end{aligned}
$$

$\delta_{T}(\operatorname{Ged} A)=C_{0} \cdot C_{1} \cdot C_{2} \cdot C_{3} \cdot S a\left(T_{e}{ }^{2} / 4 \pi^{2}\right)$. g

$=1,2.1,0.1,0.1,0.0,309\left(1,269^{2} / 4 \pi^{2}\right) 9,81$ $=0,14 \mathrm{~m}$

$\delta_{\mathrm{T}}(\operatorname{Ged} \mathrm{B})=\mathrm{C}_{0} \cdot \mathrm{C}_{1} \cdot \mathrm{C}_{2} \cdot \mathrm{C}_{3} \cdot \mathrm{Sa}\left(\mathrm{T}_{\mathrm{e}}^{2} / 4 \pi^{2}\right) \cdot \mathrm{g}$ $=1,2.1,0.1,0.1,0.0,221\left(1,803 / 4 \pi^{2}\right) 9,81$

$=0,21 \mathrm{~m}$

Maximum displacement yang terjadi dibandingkan dengan total ketinggian masing masing gedung sehingga diketahui ratio level kinerja pada masing masing gedung.

Tabel 15. Pengecekan level kinerja

\begin{tabular}{ccccc}
\hline Ged & $\begin{array}{c}\text { Target } \\
\text { Disp. }\end{array}$ & $\begin{array}{c}\text { Max } \\
\text { Disp. }\end{array}$ & Ratio & Level \\
\cline { 1 - 3 } B PD & \multirow{2}{*}{$0,21 \mathrm{~m}$} & $0,373 \mathrm{~m}$ & $1,5 \%$ & LS \\
\cline { 1 - 3 } B & & $0,373 \mathrm{~m}$ & $1,5 \%$ & LS \\
\hline $\begin{array}{c}\text { A PD } \\
\text { A }\end{array}$ & $0,14 \mathrm{~m}$ & $0,296 \mathrm{~m}$ & $0,2 \%$ & LS \\
\cline { 3 - 5 } & & $0,296 \mathrm{~m}$ & $0,2 \%$ & LS
\end{tabular}

Pada Tabel 15 masing masing maximum displacement yang terjadi pada masing masing pemodelan gedung telah melampaui target displacement yang telah diperhitungkan. 


\section{KESIMPULAN DAN SARAN}

\subsection{Kesimpulan}

Dari penelitian ini dapat disimpulkan

1. Pengaruh P-Delta Effect statik memberikan pengaruh momen pada masing masing lantai tidak melebihi $10 \%$ pada tiap tiap pemodelan gedung.

2. Pengecekan teta $(\Theta)$ P-Delta statik pada masing amsing gedung tidak ada yang melebihi teta max $(\Theta$ max) sehingga kondisi gedung tersebut stabil dan tidak perlu dilakukan desain ulang.

3. Pengaruh P-Delta Effect Dinamik yang di timbulkan tidak merubah level kinerja pada masing masing gedung.

4. Ketiga kondisi pasca gempa pemodelan gedung tersebut memenuhi syarat ATC-40 untuk gedung baru yaitu Life Safety.

\subsection{Saran}

1. Jika dilakukan penelitian yang sama sebaiknya penelitian selanjutnya dilakukan menggunakan konfigurasi gedung irregular.

2. Penelitian selanjutnya juga dapat dilakukan pertimbangan besaran pengaruh elemen non struktural kondisi bangunan pasca gempa.

\section{DAFTAR PUSTAKA}

[1] Prof. Pandian, G Agustine Maniraj. 2017. Investigation of The Effects of P-Delta on Tubular Tall Buildings. IJCIET, Vol 8: 487495

[2] Federal Emergency Management Agency. 2000. Prestandard And Comentary for The Seismic Rehabilitation of Building. FEMA 356: Washington.

[3] Badan Standarisasi Nasional. 2019. SNI 17262019 Tata Cara Perencanaan Ketahanan Gempa Untuk Struktur Gedung dan Non Gedung. BSN: Jakarta.

[4] Istiono, Heri dan Jaka Propika. 2017. Analisa Non-Linier Pada Mekanisme Keruntuhan Jembatan Rangka Baja Tipe Pratt. Borneo Engineering: Jurusan Teknik Sipil, Volume 1: 68-74. 